\title{
IMPACT OF PARTIAL REPLACEMENT OF ALFALFA HAY WITH PRICKLY PEAR PEELS ( PPPS) ON PRODUCTIVE PERFORMANCE OF RABBITS.
}

\author{
A.A. Bakr \\ Regional center for food and feed, Agricultural Research center, Giza, Egypt.
}

(Received 15/10/2019, accepted 28/11/2019)

\section{SUMMARY}

$\mathrm{F}$ orty New Zealand white rabbits (NZW) male rabbits weighed 500+6 g were used in the present study to determine the effect of using residues prickly pear peels of a source of dietary feedstuffs on productive performance, digestibility, some blood constituents and Economic efficiency of rabbit. The animals were divided into four experimental groups of 10 rabbits each. The experimental diets replacing hay with prickly pear peels (ppps) at portion $(0.0,25,50$ and $75 \%))$ respectively. Results obtained could be summarized as follow: The final live body weight, total weight gain and performance index were significantly $(p<0.05)$ affected by experimental treatment groups. The highest $(p<0.05)$ values of live body weight, total weight gain and performance index were recorded by rabbits fed $75 \%$ (ppps) Inclusion $(1986.5 \mathrm{~g}, 1489 \mathrm{~g}$ and $73.30 \%$ ) followed by received Inclusion level $50 \%$ (ppps) ( $1946.97 \mathrm{~g}, 1416.37 \mathrm{~g}$ and $68.31 \%$ ), respectively compared with the $25 \%$ (ppps) ( $1836.97 \mathrm{~g}, 1339.37 \mathrm{~g}$ and $59.45 \%$ ) or control ( $1778.75 \mathrm{~g}, 1283.45 \mathrm{~g}$ and $53.74 \%$ ),respectively. Feed intake (g), protein intake, and digestible energy intake were significantly $(\mathrm{p}<0.05)$ decreased with increasing (ppps) levels. Rabbits fed (ppps) (75\%) diet recorded a significant bester feed conversion ratio (FCR) value followed by those of $50 \%, 25$ and control respectively. Digestibility coefficient and nutritive values (DM, CP, CF, TDN and DE) were significantly improved for rabbits fed diet contained (ppps) compared to those fed the control diet. Cecal $\mathrm{PH}$ value and $\mathrm{NH}_{3}-\mathrm{N}$ concentrations were higher $(\mathrm{p}<0.05)$ in the control group than those of the treatment groups. Concentration of TVFAS was lower in control whereas the highest was obtained by treatment $75 \%$ of (ppps) $(\mathrm{p}<0.05)$. Also inclusion of tested material significantly $(\mathrm{p}<0.05)$ increased dressing percentage and carcass weight. Plasma concentrations of total proteins, albumin and globulin were increased $(\mathrm{p}<0.05)$ whereas ALT, AST, total lipids, total cholesterol, HDL and LDL were decreased $(\mathrm{p}<0.05)$ by treatments of (ppps). The best Economical efficiency and relative economical efficiency values were recorded with rabbits fed $75 \%$ (ppps) inclusion followed by rabbits received $50 \%$ and $25 \%$ treatment of (ppps) respectively it could be concluded that replacing hay with prickly pear peels (ppps) at portion $(25,50$ and $75 \%)$ into diets recorded the beneficial growth performance, nutrients digestibility, and the best Economical efficiency of NZW Rabbits.

Keywords: NZW rabbits, prickly pear peels, performance, digestibility.

\section{INTRODUCTION}

In Egypt, the reduction in local feedstuff recourses is considered as the main constrains for improving and developing animal production. Many problems confront the development of livestock one of which is shortage feedstuff and high cost of concentrate feed mixture. Therefore, it is believed that inclusion of some agricultural by products to replace a part of the concentrate diet for animal become on obligation (El-Ashry et al, 2001; Deraz and Ismail, 2001 and Bassuny et al., 2003). Increasing animal protein production in Egypt was depend upon the possibility of exploring and utilizing all possible and available resources of agriculture CO2 products in animal feeding (El-Shinnawy and Eassawy, 2016). The processing of many fruits results in accumulation of large quantities of by - products. Proper utilization of these by - products could reduce waste disposal problems and serve as a potential new source of fats and protein for use in food and feed (Kamel and Kakuda, 2002).

In Egypt, the total area annually cultivated with prickly pear (pp) was about 14100 feddans producing about 28400 tons, fruits which calculated about 13420 tons of peels (Anon ymous, 2008). Fruits of (pp) are recognized as an important source of vitamins for local people. The vegetable stems and fruits of pp are useful for a variety of purposes including food (fresh fruit, paste, jam, salads and refreshing drinks) 
fodder (auxiliary, feed for cattle, sheep and goats) and medicinal (antidiuretic agent) and for. Industrial products such as alcohol, pectin and oils (Lakshminarayana, 1980).

Cactus opuntia cladodes or cactus or opuntia prickly cladodes (pads) (COC) are known for its medicinal properties such as an auxiliary treatment for obesity and gastrointestinal or cardiovascular disorders. Also, the extracts of this material decrease level of cholesterol, triglyceride and serum glucose (Kaur, et al., 2012). The information about the usage of COC as forage source for growing rabbits is very rare in the literature. For instance, COC accumulate after processing of prickly pear that can cause environmental pollution. Prickly pears have fundamental economic importance in many desert areas especially in north Sinai, which are produced in abundant quantities. Cactus is a desertification plant and a highly palatable to wild and domesticated rabbits (Hoffman et al., 1993 and Ruiz-Feria, 1996).Its secondary compounds had antimicrobial effects by acting against bacteria, protozoa and fungi. Phenolic compounds are the main active components (Burt, 2004and Zeedan (2015).

The opuntia species cladodes serve as a source of varied number of phytoconstituents mainly sugar, phenolics and pigments. Opuntia prickly cladodes (pads) are an important source of several nutritional substances like pectin, mucilage and minerals. The pads, also known as cladodes are an excellent source of proteins including essential amino acids, high malic acid contents and good source of vitamin A, vitamin E, vitamin C, flavonoid fraction, carotenoids, chlorophylls and phenolic constituents. Several studies have reported that high levels of amino acids especially proline, taurine and serine can also be found in prickly pads (Stintzing and Carle, 2005; Feugang et al., 2006 , Cardador-Martinez et al., 2011 and Badr et.al, 2017).

Cactus opuntia cladodes are rich in potassium followed by calcium and magnesium, whereas other elements are in typical range (Batista et al., 2003 Ben Salem et al., 2005, and Badr et.al,(2017).

More recently, the antioxidant properties of the most frequent cactus pear betalains (betanin and indicaxanthin) have been revealed, anti-hyperglycemia and regulator of blood cholesterol (Tesoriere et al., 2005 and Stintzing et al., 2005). Kaur, et al. (2012) indicated that the plants of the Cactaceae family contain flavonol 3-O-glycosides (quercetin, kaempferol, and isorhamnetin), dihydroflavonols, flavonones, and flavanonols. Opuntia cladodes are an excellent energy source, rich in nonfibrous carbohydrates and presents high dry matter digestibility coefficient (Wanderley et al., 2002) and Costa et al. (2012). Demonstrated that increasing levels of cactus pear in the diet of these sheep favours a high digestibility of nutrients and improves the quality of forage. Louacini, et al. (2012) showed that the regulatory effect on blood glucose and hypolipidemic in both humans and animals.

Peels and seeds are the waste products of the pp fruits processing in dustiest ppp make about $50 \%$ of the whole fruit weight and is subsequently the major by-product while, seed constitute about $10-15 \%$ of the edible pulp and are usually discarded as waste after extraction of the pulp. Stintzing et.al. (2000) indicated that the oil processed from the seeds constitutes $7-15 \%$ of the whole seed weight and is characterized by high degree of instauration where in linoleic acid is the major fatty acid (57-77.1\%).

The fruits have a thick peel enclosing a delicately flavored very seedy pulp. There are few reports in literatures about the utilization of the peels of PP fruits. Badr et al. (2017) cleared that PPPs is a source of protein $(4.75 \%)$, carbohydrates $(59.25 \%)$, calcium $(2.04 \%)$, iron $(80.35 \%)$, zinc $(37.49 \mathrm{mg} / \mathrm{kg})$, copper $(1.92 \mathrm{mg} / \mathrm{kg})$, phosphorous $(0.9 \%)$, mannan $(7.76 \%)$, beta-glucan $(27.25 \%)$ and B-carotene $(141.4 \mathrm{ug} / 100 \mathrm{~g})$. PPPs content of hemicellulose, cellulose and lignin were $0.5,10.92 \%$ and $1.2 \%$, respectively. Amino acid profile ensured the existence of fifteen amino acids of which seven were essentials: leucine $(0.22 \%)$, valine $(0.19 \%)$, lysine $(0.11 \%)$, phenylalanine $(0.14 \%)$, threonine $(0.14 \%)$, isoleucine $(0.15 \%)$ and histidine $(0.09 \%)$. The remaining amino acids were aspartic acid $(0.28 \%)$, arginine $(0.15 \%)$, alanine $(0.19 \%)$, proline $(0.23 \%)$, glutamic acid $(0.32 \%)$, glycine $(0.18 \%)$ and serine $(0.14 \%)$. So, the chemical composition indicated that PPPs is rich (on dry matter basis) in its content especially in readily digestible carbohydrate that it is may serve as a good source of fermentabie ME. Although it has been used as an animal feed its value especially for farm animals, has received little research attention. One of the major needs within the PP industry is the development of new processed PP products as well as the fruit by products. These new functional components from prickly pear peel open new possibilities for adding value to a very ancient, but not sufficiently known, crop of the arid and semiarid regions. The expansion of the PP cultivation in arid and semi-arid areas could be of interest for stimulating bioindustries in developing countries (Terrazas et al., 2002).

The objective of this experiment was to examine the effects of replacing hay with prickly pear peels (ppps) contained diets on production, performance, nutrient digestibility coefficients, blood constitutes and economic efficiency of growing rabbits. 


\section{MATERIALS AND METHODS}

The present study was carried out in the rabbit try farm of poultry production Department, faculty of Agriculture, Elsharkia,zkazikUniversity and Regional center for food and feed (RCFF), Agric.Res. Center (ARC), Ministry of Agric., Giza, Egypt. This work designed to study the influence of replacing hay with prickly pear peels (ppps) at portion $(25,50$ and $75 \%$ ) at different levels on growth performance, digestibility, and economic evaluation of growing New Zealand white rabbits.

\section{Preparation of the dried powder of PPPs and feed ingredients:}

The prickly pear peels (PPPs) were collected from local market of Giza Governorate during summer season (August 2016). The peels were dried by spreading in direct sun after being chopped (about $3 \mathrm{~cm}$ length). The peels were shuffled upside-down and mixed well every day until its moisture content regressed to about $20 \%$. Complete drying was done by using an oven at 55C for $8 \mathrm{~h}$., the dried peels and feed ingredients were grounded in a blender for $5 \mathrm{~min}$ and packed in polyethylene bags until analysis.

\section{Chemical analysis:}

Representative samples of feed ingredients and experimental rations were taken for proximate analysis according to the procedures of AOAC (2002).

\section{Fiber fraction analysis:}

Natural detergent fiber (NDF), Acid detergent fiber (ADF) and acid detergent lignin (ADL) contents of feed ingredients and experimental rations were determined by analysis of fiber fraction according to Van Soest et.al. (1991). Cellulose (CEL) and hemicellulose (HEM.) content were calculated respectively, by subtracting ADL from ADF and ADF from NDF.

\section{Experimental animals:-}

Forty weaned New Zealand White rabbits (NZW) of male rabbits aged 35 days and weighed 500+6 on average were equally and randomly divided into four groups (10 in each one).

\section{Feeding and drinking management:-}

Feed and water were offered adlibitum throughout the experimental period from 5 to 14 weeks of age. All rabbits were nearly equal in live body weight at the beginning of the experiment. All nutrients, essential amino acids, minerals and vitamins in the experimental diets were adjusted according to the rabbit requirements of NRC (1977). All the experimental animals were healthy and clinically free from internal and external parasites and were kept under the same management and hygienic conditions. Table (1) shows the composition and calculated analysis of the experimental diets. The first group was fed adlibitum, throughout experiment period from 5 to 14 weeks of age, a pelleted diet and kept untreated and served as a control. While the other groups (second, third and fourth) were fed with pellet replaced with levels of hay 25,50 or $75 \%$ dried prickly pear peels (PPP), respectively.

\section{Growth performance:-}

Rabbits were weighed in the morning before receiving feed or water and feed intake was recorded biweekly during the experimental period. Body weight gain (BWG) was calculated by subtracting the initial live body weights from final ones of each growth period. Feed conversion ratio (FCR) was obtained by dividing the amount of total feed intake (TFI) on the corresponding weight gain. Also, performance index (PI) was calculated according to North (1981). Average protein and digestible energy intakes were calculated by multiplying feed intake by percent of protein and digestible energy contents of experimental diets.

\section{Digestibility trial:-}

The collection period lasted for 5 days. Feed intake was measured and feces output was collected daily. Hair and scattered feed were separated or taken out of the feces. The collected feces for rabbits of each treatment was pooled together, and dried at $60 \mathrm{C}$ till constant weight. The dried feces for the successive five days was left few hours to get equilibrium with the atmosphere and then ground, well mixed and stored in screw-top glass jars for chemical analysis. Chemical analysis was carried out for diets and feces according to methods of AOAC (2002). The values of total digestible nutrients (TDN) and digestible crude protein (DCP) were calculated according to the classic formula (Cheeke et al., 1982). DE $(\mathrm{kcal} / \mathrm{kg} \mathrm{DM})=4253-32.6(\mathrm{CF} \%) 144.4($ Ash \%), according to Fekete and Gippert (1986). 


\section{Bakr}

Table (1) Composition and calculated analysis of the experimental diets

\begin{tabular}{|c|c|c|c|c|}
\hline \multirow{2}{*}{ Ingredient $\%$} & \multicolumn{4}{|c|}{ Prickly pear peel } \\
\hline & Control & $25 \%$ & $50 \%$ & $75 \%$ \\
\hline Alfalfa hay & 32 & 24 & 16 & 8 \\
\hline Soy bean seed, meal (44\%) & 7.5 & 7.5 & 7.5 & 7.5 \\
\hline Prickly pear peels & 0 & 8 & 16 & 24 \\
\hline Corn Gluten meal & 5 & 5.4 & 5.9 & 6.4 \\
\hline Yellow corn & 12.15 & 11.05 & 9 & 7 \\
\hline Calcium phosphate dibasic & 0.5 & 0.5 & 0.5 & 0.5 \\
\hline Sun flower oil & 1.39 & 1.29 & 1.29 & 1.29 \\
\hline Molasses & 3 & 3 & 3 & 3 \\
\hline Wheat bran & 24.33 & 25.03 & 26.33 & 27.5 \\
\hline Salt & 0.5 & 0.5 & 0.5 & 0.5 \\
\hline Premix & 0.3 & 0.3 & 0.3 & 0.3 \\
\hline Limes tone & 1.25 & 1.35 & 1.6 & 1.9 \\
\hline L-lysine $\mathrm{Hcl}$ & 0.05 & 0.05 & 0.05 & 0.05 \\
\hline DL Methionine & 0.33 & 0.33 & 0.33 & 0.33 \\
\hline Total & 100 & 100 & 100 & 100 \\
\hline \multicolumn{5}{|l|}{ Calculated analysis** } \\
\hline $\mathrm{DE}, \mathrm{Kcal} / \mathrm{kg}$ & 2529 & 2534 & 2537 & 2539 \\
\hline Crude protein $(\mathrm{CP})$ & 16.63 & 16.42 & 16.29 & 16.15 \\
\hline Ether extract (EE) & 3.93 & 3.94 & 4.03 & 4.13 \\
\hline NFE & 58.24 & 59.81 & 61.18 & 62.95 \\
\hline $\mathrm{Ca} \%$ & 1.11 & 1.03 & 1.01 & 1.01 \\
\hline Total P\% & 0.62 & 0.6 & 0.6 & 0.59 \\
\hline Lys \% & 0.701 & 0.63 & 0.62 & 0.59 \\
\hline Meth \% & 0.6058 & 0.59 & 0.58 & 0.58 \\
\hline $\mathrm{CF} \%$ & 14 & 12.4 & 10.7 & 9.09 \\
\hline
\end{tabular}

* Each $3 \mathrm{~kg}$ of vit and Min in Premix contain: 6000000IU vit A, 900000 IU vit D3 40000mg vit E,2000mg vit $K$, 2000mg vit.B1, 4000mg vit B2, 2000mg vit B6, 10mg vit B12, 50000mg Niacin, $10000 \mathrm{mg}$ pantothenic acid, 50mg Biotin, 3000mg Folic acid, $250000 \mathrm{mg}$ choline, 50000mg Zn, 8500mg Mn, 50000mg Fe, 50000mg Cu, 200mg I, 100mg Se and 100mg Co.

** According to NRC (1977).

\section{Cecum samples:-}

Samples of cecum content were individually taken from rabbits of each group and cecum contents were obtained after slaughtering and filtrated to estimate $\mathrm{PH}$ and cecum micro flora. Cecum ammonianitrogen determination was carried out as soon as possible using the steam distillation method described by Ahmed (1976). Cecum total volatile fatty acids (VFAs) content was measured according to AOAC (1995).

\section{Carcass characteristics:-}

At the end of the experimental period (14weeks of age), a total number of 20 rabbits (five rabbits from each group) were randomly taken for slaughter. Assigned rabbits were fasted for 16 hours before slaughtering and individually weighed as pre-slaughter weight. Animals were slaughtered by cutting the jugular veins of the neck, when complete bleeding was achieved, slaughter weight was recorded. After skinning, the carcass was opened down and all entrails were removed and the empty carcass, heart, liver, kidneys and spleen were separately weighed, each of them was proportioned to the live pre-slaughter weight. Dressing percentage was calculated according to Steven et al. (1981).

\section{Biochemical parameters:-}

Blood samples were taken at the time of slaughter and then centrifugated at 3000 r.p.m. for 20 minutes to obtain plasma and kept at $-20 \mathrm{C}$ until analysis. Blood plasma was assigned for determination of total protein, albumin, urea - N, cholesterol, Low Density Lipoprotein (LDL cholesterol), High Density Lipoprotein (HDL cholesterol), Triglecride and liver function (aspartate aminotransferase "AST" and alanine aminotransferase "ALT"). Non-coagulated blood was tested shortly after collection for estimating blood pictures. White and red blood cells were counted according to Feldman et al. (2000). 


\section{Statistical analysis:-}

Data were analyzed according to the statistical analysis system user guide, (SAS 1998). Separating among means was carried out by using Duncan multiple test, (Duncan, 1955).

\section{RESULTS AND DISCUSSION}

\section{The chemical composition of prickly pear peels (PPPs) and Alfalfa hay}

The chemical compositions of feed Ingredients are presented in Table (2). The results showed that the chemical composition of alfalfa hay were within the corresponding ranges reported by El-Shinnawy et al (2011) and Badr et al. (2017). The data for chemical composition of PPPs were in agreement with those obtained by (Gregory and Felker, 1992; Felker, 1995; Lopez et al., 2001; El-said et al. 2011 and Badr et al., 2017).

Table (2): The chemical analysis of prickly pear peels and Alfalfa hay

\begin{tabular}{|c|c|c|c|c|c|c|c|c|c|c|}
\hline Item & $\mathrm{OM}$ & $\mathrm{CP}$ & $\mathrm{EE}$ & $\mathrm{CF}$ & NFE & $\mathrm{NDF}$ & ADF & $\mathrm{ADL}$ & ASH & $\mathrm{DE}^{*}$ \\
\hline Prickly pear peels & 89.37 & 6.50 & 3.76 & 8.9 & 69.31 & 14.82 & 11.06 & 2.70 & 11.53 & 2298 \\
\hline $\begin{array}{l}\text { Alfalfa dehydrated } \\
\text { meal }\end{array}$ & 81.20 & 13.3 & 2.33 & 33.33 & 41.24 & 62.2 & 44.4 & 11.27 & 9.8 & 1751 \\
\hline
\end{tabular}

It showed that PPPs had lower content of CP (6.50), CF (8.9), NDF (14.82), ADF (11.06) and ADL (2.7\%) while, it had higher values of NFE (69.31) EE (3.76) and DE (2298) when compared with Alfalfa hay. This results reported by (Dekock, 1980; Flachowsky and Yami, 1985; and Hanselka and Paschal, 1990). The NDF content of PPPs obtained in this study is higher than that reported by Amare et al. (2009). Badr et al. (2017) reported that it contains $4.75 \% \mathrm{CP}$, carbohydrates $59.25 \%$, fiber $3.15 \%$ fat $3.55 \%$ and Ash $11.00 \%$.

\section{Chemical analysis of the rations:-}

All experimental rations were iso-caloric and iso-nitrogenous approximately (Table 1). The chemical analysis of different experimental rations was in the same range approximately for CP, EE, CF, NFE and DE contents. The percentages of crude protein ranged from 16.15 to $16.63 \%$ ether extract content was ranged from 3.93 to $4.13 \%$ crude fiber content 9.09 to $14 \%$ nitrogen free extract content was ranged from 58.24 to 62.95 and digestible energy ranged from 2529 to $2539 \mathrm{kcal} / \mathrm{kg}$ for the four tested rations. The variation in chemical composition may be related to differ in source of roughage incorporated in rations formulation.

\section{Growth performance:-}

Results in Table (3) shows that the final live body weight, total body weight gain and performance index were significantly $(\mathrm{P}<0.05)$ affected by experimental treatments. The highest $(\mathrm{P}<0.05)$ values of live body weight, total body weight gain and performance index were recorded by rabbits of treatment $75 \%$ PPPs (1986.5g, 1489g and 73.30\%followed by those of 50\% PPPs (1946.97 g, 1446.37g and $68.31 \%)$ respectively compared with the other experimental treatments. While the lowest $(\mathrm{P}<0.05)$ live body weight, total body weight gain and performance index were recorded the control group $(1778.75 \mathrm{~g}$, $1283.45 \mathrm{~g}$ and $53.74 \%$ ) respectively. These results are in agreement with results of Atti, et al. (2009) and Aguilar-yanez et al (2011). Ruiz-feria et al (1998) reported that fed rabbits leucaena inclusion had the poorest performance, whereas the opposite was true with diet of $10 \%$ cactus, growth traits was improved Gebremariam et al (2006) concluded that inclusion of cactus in the experimental diet or other comparable diets to up to $50 \%$ on DM basis for sheep fed tefstraw promotes weight gain without causing digestive disturbances. Abu shammalah (2007). Reported that the average final body weights of the growing rabbit age 56 days fed $20 \%$ and $40 \%$ cactus opuntia cladodes (COC) were relatively similar to the average final body weights of control. Taddesse, et al. (2014) reported that supplemented spineless cactus goats $(150 \mathrm{~g} / \mathrm{head} / \mathrm{dcactus})$ had higher final BW and mean daily BW gain as compared to the control. 
Improvement growth performance may be attributed to mode of action of PPP including the maintaining a beneficial microbial population and improving digestion. The increased live weight gain in rabbits fed PPPs diets can be explained by the associative effects of high soluble carbohydrates contained the cactus. Also cactus is a desertification plant and a highly palatable to wild and domesticated rabbits. Prickly pear peels (ppp) are an important source of several nutritional substances like pectin, mucilage and minerals. The prickly pear peels (ppp) also known as an excellent source of proteins including essential amino acids, high malic acid contents and good source of vitamin, flavonoid fraction, carotenoids and phenolic constituents. Several studies have reported that high levels of amino acids especially proline, valine, serine and proline can also be found in prickly pear (Stintzing and Carle, 2005; Feugang et al., 2006, Cardador Martinez et al., 2011 and Badr et al., 2017).General cladodes are rich in pectin, mucilage and minerals, whereas the fruits are good sources of vitamins, amino acids and betalains (Habibi et al., 2005).Cowan, (1999) reported that plant derived products contain a great diversity of photochemical such as phenolic acids, flavonoids and tannins. These increments in live body weight and body weight gain may be attributed to increasing digestion of all nutrients (Table 3 ), decreasing $\mathrm{PH}$, $\mathrm{NH}_{3}-\mathrm{N} \mathrm{mmol} / \mathrm{L}$ ). concentration and the increasing of VFA in the cecum, according improving the nutrients utilization may be attributed to the conversion of ammonia- $\mathrm{N}$ into microbial protein for the benefit of rabbits which characterized by the pseudo- rumination.

\section{Feed intake and feed conversion:-}

The data shows that there is significant effect of treatment PPPs on total feed intake (TFI), feed conversion ratio (FCR), protein intake, (PI) and digestible energy intake of rabbits (Table 4). Feed intake (g/day), protein intake, and digestible energy intake significantly $(\mathrm{P}<0.05)$ decreased with increasing PPPs levels containing diets. Rabbits fed PPPs diet recorded significantly better FCR values. Prickly pear peels (PPPs) improved the feed digestibility and utilization of ammonia and (PPPs) constituted of like minerals, sugars, organic acid, amino acids, lipids, terpenes, high malic acid contents, good source of vitamin A, vitamin C, flavonoid, carotenoids, chlorophylls and phenolic constituents. The decrease of feed intake in rabbit fed PPPs could be explained by the in nutrient supply such as minerals and water soluble vitamins could accelerate nutrients metabolism and increase energy digestibility. Also, PPPs can improve the condition of the intestines and enhances the overage daily weight gain and digestibility. These results are in agreement with finding of Gebremariam, et al.,(2006), Einkamerer (2008), Einkamerer,et al.,(2009), Menezes, et al.,(2010) and Badr Azza (2017) in sheep, Mendez- Liorenteet al.,(2008) and Aguilar. Yanez,et al.,(2011) in lambs.

Table (3): Effect of dietary PPP levels on growth performance of growing rabbits

\begin{tabular}{|c|c|c|c|c|c|}
\hline Treatments & Zero & 1 & 2 & 3 & L.S.D \\
\hline Initial live body weight & $495.3^{\mathrm{a}}$ & $497.6^{\mathrm{a}}$ & $500.6^{\mathrm{a}}$ & $497.5^{\mathrm{a}}$ & N.S \\
\hline Final live body weight & $1778.75^{\mathrm{b}}$ & $1836.97^{\mathrm{b}}$ & $1946.97^{\mathrm{a}}$ & $1986.5^{\mathrm{a}}$ & 75.4751 \\
\hline Total weight gain & $1283.42^{\mathrm{b}}$ & $1339.37^{\mathrm{b}}$ & $1446.37^{\mathrm{a}}$ & $1489^{\mathrm{a}}$ & 80.1467 \\
\hline Average weight gain & $22.91^{\mathrm{b}}$ & $23.92^{\mathrm{b}}$ & $25.28^{\mathrm{a}}$ & $26.58^{\mathrm{a}}$ & 1.4277 \\
\hline Feed intake $(\mathrm{FI})$ & $4248^{\mathrm{a}}$ & $4150^{\mathrm{b}}$ & $4120^{\mathrm{b}}$ & $4040^{c}$ & 69.0262 \\
\hline Feed conversion ratio(FCR) & $3.31^{\mathrm{a}}$ & $3.09^{\mathrm{b}}$ & $2.85^{\mathrm{c}}$ & $2.71^{\mathrm{c}}$ & 0.20888 \\
\hline Performance index & $53.74^{\mathrm{c}}$ & $59.45^{\mathrm{c}}$ & $68.31^{\mathrm{b}}$ & $73.30^{\mathrm{a}}$ & 5.8118 \\
\hline Protein intake(PI) & $706.44^{\mathrm{a}}$ & $684.03^{\mathrm{b}}$ & $671.14^{\mathrm{c}}$ & $652.45^{\mathrm{d}}$ & 11.0152 \\
\hline Protein efficiency ratio (PER) & $1.82^{\mathrm{d}}$ & $1.96^{\mathrm{c}}$ & $2.16^{\mathrm{b}}$ & $2.28^{\mathrm{a}}$ & 0.12513 \\
\hline Digestible energy index & $10743.19^{\mathrm{a}}$ & $10516.1^{\mathrm{b}}$ & $10452.44^{\mathrm{b}}$ & $10257.56^{\mathrm{c}}$ & 174.9400 \\
\hline Efficiency of energy utilization & $8.37^{\mathrm{a}}$ & $7.85^{\mathrm{b}}$ & $7.23^{c}$ & $6.88^{c}$ & 0.53113 \\
\hline No. of dead Rabbits & 1 & 1 & - & - & \\
\hline
\end{tabular}

Abu Shammalah (2007) reported that average feed intake, g/day in rabbits fed Opuntia cladodes (COC) were 87.60, 63.80, 53.00 and $34.60 \mathrm{gm}$. for control, 20\%, 40\% and 60\% respectively. Zeedan et al. (2015) reported that feed intake (g/day), protein intake, and digestible energy intake were significantly $(\mathrm{P}<0.05)$ decreased with increasing cladodes Opuntia cladodes $(\mathrm{COC})$ in fed rabbits. The increase prickly pear peels (PPPs) level significantly $(\mathrm{P}<0.05)$ improved feed conversion compared to control diet (Table 3). 
Significant differences among administration were found for the FCR, it was noted that the best FCR $(2.71,2.85)$ was recorded for rabbits fed with $75 \%$ and $50 \%$ respectively followed by those treated $25 \%$ (3.09 this finding is very consistent with those reported by Abu Shammalah (2007) who reported that average feed conversion ratios in rabbits fed the control diet c, either $20 \%, 40 \%$ or $60 \%$ were $3.33,3.01$, 2.85 and 3.25 respectively. Zeedan et al. (2015) reported that rabbits fed cactus opuntia cladodes (COC) $30 \%$ diet recorded a significant bester FCR value followed by those of 20 and $10 \%$ tested material respectively.

These improvements in FCR and lower feed intake may be attributed to PPPs inclusion decreases $\mathrm{NH}_{3}-\mathrm{N}$ (Table 5) and increases digestion of all nutrients (Table 5). In the present experiment, improved FCR with PPPs inclusion may be due to improve their crude protein digestibility and improve nutrient utilization of flavonoids and phenolic acids contained PPPs. Also the improvement of FCR of PPPs level may be due to a beneficial microbial environment in the gut which might have enhanced digestion digestion, absorption and utilization of nutrients. Also the improvement of FCR may be due to the antioxidant, antibacterial, antimicrobial and anti-inflammatory activity as well as nutrient utilization depended on the presence of flavonoids and phenolic acids (Ennouri, et al., 2014, Cawan, 1999) and Badr et al., 2017).

\section{Mortality rate:-}

Results indicated that there is no dead for experimental groups fed $50 \%$ and $75 \%$ (PPPs) inclusion (Table 3). It may be due to immune system compared to the control group. The decrease in mortality may be due to the decrease in $\mathrm{PH}$ and $\mathrm{NH}_{3}-\mathrm{N}$, in the cecum which leading to decrease the diarrhea. Also, to the antibacterial, antimicrobial and anti-inflammatory activity effect of PPPs and improving nutrient utilization due to the presence of flavonoids and phenolic acids, (Ennouri, et al., 2014) and (Cawan, 1999) reported that prickly pear products contain agreat diversity of phytochemicals such as phenolic acids, flavonoids and tannins, Badr et al. (2017) found that numerous health related effects such as antibacterial, antigenic, ant carcinogenic, antithrombotic and rascodilatory activities. Increasing globulin concentration with increased PPPs inclusion explains the decrease in the mortality.

\section{Digestibility and nutritive value:-}

Table (4) Shows that the digestibility of all nutrients were significantly $(\mathrm{P}<0.05)$ increased by increase PPPs inclusion. These results are in agreement with Einkamerer (2008), Costa, et al.,(2012 and Menezes et al. (2010). Gregory and Felker (1992) reported that prickly pear cactus has hight dry matter digestibility and also to be highly palatable to wild and domesticated rabbits. Zeeman (2005) reported that digestibility of most chemical constituents significantly increased $(\mathrm{P}<0.05)$ in line with increased Opuntia inclusion and the low fiber content of Opuntia is positively correlated with DM digestibility. Ben salem et al. (1996) concluded that the apparent DM digestibility increases with addition of Opuntia cladodes due to its higher easily digestible carbohydrate content. Also, Zeeman (2005) found that ascribed the higher digestibility to the fact that Opuntia cladodes contain higher levels of easily digestible carbohydrates. The highest digestibility was observed in the treatment of 75\% PPPs followed by the diet of 50\% PPPs, $25 \%$ PPPs, respectively. Despite the low nutrimental quality of the spineless cactus, it conferred a better digestibility, given the high fermentative capacity of its carbohydrates (Misra et al., 2006). Digestible organic matter is important for ruminal microbial protein synthesis as an energy source. This difference may be due to the high content of non-structural carbohydrates (NSC) found in cactus. Tegegne, et al. (2005) found that the high concentration of soluble carbohydrates in cactus facilitates the incorporation of nitrogen into microbial protein, which is the main source of metabolizable protein for the host animal. The highest digestibility of all nutrients in treated groups can be discussed from the point that PPPs contains minerals ( $\mathrm{Mg}, \mathrm{Ca}, \mathrm{K}, \mathrm{Na}, \mathrm{Cu}, \mathrm{Zn}, \mathrm{Mn}, \mathrm{P}$ and $\mathrm{Fe}$ ), amino acid, high malic acid contents, vitamin A, vitamin E, vitamin C, flavonoid, carotenoids, phenolic constituents, which may be associated with improvement in digestibility of all nutrients (Stintzing and Carle, 2005, Habibi et al., 2005, Feugang et al., 2006, Abu Shammalah, 2007, Cardador.Martinez et al., 2011, Cordova-Torres et al., 2015 and Badr et al. 2017).

The compounds with antimicrobial effect maintained the health of the digestive tract and improved both digestion and absorption. Consequently, the improving in the nutrients digestibility, for treated groups may be reflected a better growth performance as shown in Table (3). Apportion of the increase in digestibility may have resulted from the reduction of intake that occurred. It is well documented that digestibility of the diet increases with decreasing intake (NRC, 1977 and Zeedan et al. (2017).

In this study, the results showed that the use of PPPs improved digestibility of nutrients and absorption this reaction can lead to increase feed utilization and improve performance. 


\section{Bakr}

Table (4): Digestibility coefficient of the experimental rations

\begin{tabular}{|c|c|c|c|c|c|c|}
\hline Parameter & Treatment & Control & $25 \%$ & $50 \%$ & $75 \%$ & L.S.D \\
\hline \multicolumn{7}{|c|}{ Digestion coefficient $\%$} \\
\hline $\mathrm{DM}$ & & $65.22 \mathrm{c}$ & $65.82 \mathrm{bc}$ & $66.53 b$ & $67.74 \mathrm{a}$ & 1.1067 \\
\hline $\mathrm{CP}$ & & $65.48 \mathrm{c}$ & $66.50 \mathrm{bc}$ & $67.23 \mathrm{ab}$ & $68.28 \mathrm{a}$ & 1.1639 \\
\hline $\mathrm{EE}$ & & $67.92 \mathrm{c}$ & $68.43 c$ & $69.23 b$ & $69.95 \mathrm{a}$ & 0.7197 \\
\hline $\mathrm{CF}$ & & $46.27 d$ & $48.43 \mathrm{c}$ & $51.51 \mathrm{~b}$ & $53.75 a$ & 0.8123 \\
\hline NFE & & $69.90 \mathrm{~d}$ & $72.44 \mathrm{c}$ & $75.62 b$ & $77.98 \mathrm{a}$ & 1.2013 \\
\hline $\mathrm{NDF}$ & & $43.28 \mathrm{~d}$ & $44.64 \mathrm{c}$ & $45.87 b$ & $47.94 \mathrm{a}$ & 0.7581 \\
\hline $\mathrm{ADF}$ & & $41.01 \mathrm{~d}$ & $43.43 c$ & $44.69 b$ & $45.90 \mathrm{a}$ & 0.9849 \\
\hline ADL & & $33.86 \mathrm{~d}$ & $35.86 \mathrm{c}$ & $37.59 b$ & $38.35 \mathrm{a}$ & 0.5768 \\
\hline \multicolumn{7}{|l|}{ Nutritive values } \\
\hline TDN \% & & $61.38 \mathrm{~d}$ & $62.42 \mathrm{c}$ & $64.52 b$ & $66.48 \mathrm{a}$ & 0.7981 \\
\hline $\mathrm{DCP} \%$ & & $10.88 \mathrm{a}$ & $10.92 \mathrm{a}$ & $10.95 \mathrm{a}$ & $11.02 \mathrm{a}$ & $*$ N.S \\
\hline $\mathrm{DE}^{* *}(\mathrm{Kcl} / \mathrm{Kg})$ & & $2719.43 d$ & $2765.35 c$ & $2858.23 b$ & $2945.36 \mathrm{a}$ & 35.3584 \\
\hline
\end{tabular}

$a, b$ and means in the same row bearing different superscripts are significantly different.

*: $P \leq 0.05, N S:$ not significant.

$* * D E(\mathrm{kcal} / \mathrm{kg})=T D N \times 44.3$.

\section{Cecum traits:-}

The cecum PH, ammonia-N concentrations and total VFN concentrations ( $\mathrm{mmol} / \mathrm{L}$ ) of cecum contents are presented in Table (5). Cecum PH value is one of the most important factors, which effect microbial fermentation in the cecum and influences their functions concerning the values of caecal $\mathrm{PH}$, there were significant $(\mathrm{P}<0.05)$ lower $\mathrm{PH}$ and $\mathrm{NH}_{3}-\mathrm{N}$ with increasing PPPs. The lowest acidity was recorded for rabbits treatment fed $75 \%$ PPPs inclusion. The increasing PPPs resulted in more fermentation in the caecal, thus reduced caecal $\mathrm{PH}$ as a result of increasing volatile fatty acids production.

Table (5): Effect of prickly pear peels (ppps) levels on Cecal fermentation activity of growing rabbits

\begin{tabular}{lccccc}
\hline Item & Control & $25 \%$ & $50 \%$ & $75 \%$ & L.S.D \\
\hline Cecum PH & $6.85^{\mathrm{a}}$ & $6.53^{\mathrm{b}}$ & $6.15^{\mathrm{c}}$ & $5.67^{\mathrm{d}}$ & 0.29889 \\
$\mathrm{NH}_{3}-\mathrm{N}(\mathrm{Memel} / \mathrm{L})$ & $20.16^{\mathrm{a}}$ & $19.30^{\mathrm{a}}$ & $17.72^{\mathrm{b}}$ & $16.61^{\mathrm{c}}$ & 0.99420 \\
Total VFA(Memel/L) & $49.94^{\mathrm{d}}$ & $46.50^{\mathrm{c}}$ & $62.28^{\mathrm{b}}$ & $65.73^{\mathrm{a}}$ & 2.97257 \\
\hline
\end{tabular}

Table (6): Effect of prickly pear peels levels on some carcass traits of growing rabbits

\begin{tabular}{|c|c|c|c|c|c|}
\hline Item & control & $25 \%$ & $50 \%$ & $75 \%$ & L.S.D \\
\hline Pre. Slaughter weight(g) & $1798.75^{\mathrm{b}}$ & $1856.97^{\mathrm{b}}$ & $1976.97^{\mathrm{a}}$ & $1996.5^{\mathrm{a}}$ & 75.47513 \\
\hline Carcass weight $(\mathrm{g})$ & $828.66^{b}$ & $876.12^{\mathrm{b}}$ & $964.80^{\mathrm{a}}$ & $1057.47^{\mathrm{a}}$ & 71.139171 \\
\hline Dressing weight $(\mathrm{g})$ & $891.08^{\mathrm{b}}$ & $952.63^{\mathrm{b}}$ & $1055.35^{\mathrm{a}}$ & $1156.3^{\mathrm{a}}$ & 71.46524 \\
\hline Dressing \% & $49.54^{\mathrm{b}}$ & $51.30^{\mathrm{b}}$ & $53.38^{\mathrm{a}}$ & $57.91^{\mathrm{a}}$ & 1.867127 \\
\hline Total giblets weight $\%$ & $3.47^{\mathrm{d}}$ & $4.12^{\mathrm{c}}$ & $4.58^{\mathrm{b}}$ & $4.95^{\mathrm{a}}$ & 0.30794 \\
\hline Heart & $0.45^{\mathrm{a}}$ & $0.46^{\mathrm{a}}$ & $0.46^{\mathrm{a}}$ & $0.47^{\mathrm{a}}$ & $\mathrm{NS}^{*}$ \\
\hline Liver & $2.01^{\mathrm{d}}$ & $2.33^{\mathrm{c}}$ & $2.67^{b}$ & $2.95^{\mathrm{a}}$ & 2.72983 \\
\hline Kidney & $1.01^{\mathrm{c}}$ & $1.33^{\mathrm{c}}$ & $1.45^{\mathrm{b}}$ & $1.53^{\mathrm{a}}$ & 1.038740 \\
\hline \multicolumn{6}{|c|}{ Chemical analysis of carcass meat on DM basis $\%$} \\
\hline & Control & $25 \%$ & $50 \%$ & $75 \%$ & L.S.D \\
\hline Moisture \% & $7.18^{\mathrm{a}}$ & $7.13^{\mathrm{a}}$ & $7.21^{\mathrm{a}}$ & $7.52^{\mathrm{a}}$ & NS \\
\hline $\mathrm{CP} \%$ & $19.19^{c}$ & $20.12^{\mathrm{b}}$ & $20.22^{\mathrm{b}}$ & $21.05^{\mathrm{a}}$ & 0.714468 \\
\hline $\mathrm{EE} \%$ & $2.96^{\mathrm{a}}$ & $3.05^{\mathrm{a}}$ & $2.70^{\mathrm{b}}$ & $2.23^{\mathrm{c}}$ & 0.257015 \\
\hline Ash \% & $1.79^{\mathrm{a}}$ & $1.62^{\mathrm{ab}}$ & $1.51^{\mathrm{b}}$ & $1.43^{\mathrm{b}}$ & 0.241855 \\
\hline
\end{tabular}

$a, b, c$ and $d$ Means in the same row bearing different superscripts are significantly different.

$* P \leq 0.05$, NS: not significant.

These results are in agreement with those reported by Bisop, et al. (2007), Mendez. Liorente, et al. (2008) in sheep, Vieira, et al. (2008) in goats and Zeedan, et al. (2015) found that cecal PH value and 
$\mathrm{NH}_{3}-\mathrm{N}$ concentration were higher $(\mathrm{P}<0.05)$ in the control group than those fed with 30,20 and $10 \%$ Cactus Opuntia cladodes (COC).

On the other hand, Misra, et al. (2006) found that ruminal $\mathrm{NH}_{3}-\mathrm{N}$ was not significantly different between lambs fed 0,10 and 20\% cactus Opuntia cladodes (COC) but were higher than 30 and $40 \%$. High cactus Opuntia $(\mathrm{COC})$ inclusion significantly increased $(\mathrm{P}<0.05)$ the concentration of total VFA compared to control. The used of PPPs that is probably the most interest to rabbit's producers is as an antimicrobial and antioxidants Zeedan, et al. (2015) (The flavonoids, phenolic components play a significant role in the free radical scarenging capacity of cactus opuntia cladodes (COC) (Abu Shammalah 2007 and Cardador-Martinez et al., 2011). The increased total VFA may be attributed to the effect of decreasing $\mathrm{PH}$ and $\mathrm{NH}_{3}-\mathrm{N}$ increased the digestible protein and TDN with high PPPs level (Table 4). The decreased cecum PH, the decreased ammonia-N concentration and the higher VFA concentration suggest active microbial synthesis existed in the cecum. Also, decreasing $\mathrm{NH}_{3}-\mathrm{N}$ concentration may be attributed to the conversion of ammonia- $\mathrm{N}$ into microbial protein for the benefit of rabbits which characterized by the pseudo-rumination and improvement in digestion of nutrient in Table (4). (Zeedan et al., 2015). On the other hand, Ben salem and Smith (2008) reported that the high content of sugars in cactus pear did not affect ruminal fermentation in sheep.

\section{Carcass characteristics and chemical composition:-}

Results in Table (6) show that significant variation between dietary treatments of PPPs for all carcass characteristics. Rabbits fed 75\% PPPs had the highest value all carcass characteristics than other rabbit's treatments groups. The increase in carcass traits for treated groups may be mainly related to the increase in growth performance and digestibility. These results are agreement with (Zeedan et al., 2015) who found that rabbits received 30\% cactus opuntia cladodes (COC) had the highest value all carcass characteristics than other rabbit's treatments groups. Mahouachi, et al., (2012). Ruiz. Feria et al., (1998) who evaluated that rabbits fed leucaena had the poorest performance, but when fed $10 \%$ level cactus, growth and carcass traits were improved. Abu Shammalah (2007) found that the carcass weight, kidneys, spleen and liver of rabbits significanteffect $(\mathrm{P}<0.05)$ with cactus supplementation. On the ther hand Attie et al., (2006) showed that the carcass weight of goat kids decreased significantly $(\mathrm{P}<0.05)$ with cactus supplementation.

Generally, the increase in carcass traits in treated groups can be discussed from the point that PPPs contains minerals ( $\mathrm{Mg}, \mathrm{Ca}, \mathrm{K}, \mathrm{Na}, \mathrm{Cu}, \mathrm{Zn}, \mathrm{Mn}, \mathrm{P}$ and $\mathrm{Fe}$ ), amino acid, high malic acid contents, vitamin A, vitamin E, vitamin C, flavonoid, carotenoids, phenolic constituents, which may be associated with improvement in digestibility of all nutrients (Stintzing and Carle, 2005, Feugang et al., 2006, Abu Shammalah, 2007, Cardador.Martinez et al., 2011 ,Cordova-Torres et al., 2015)and Zeedan et al., 2015.

Concerning the chemical analysis for carcass (Table 6),the results shows a significant effect was found as feeding PPPs inclusion with in crude protein (CP), ether extract (EE) and ash of meat. Zeedan et al., (2015)found that results shows a significant effect was found as feeding (COC) inclusion with in crude protein (CP), ether extract (EE) and ash of meat on the other hand Mahouachi, et al., (2012) reported that no significant differences were found for moisture, crude protein, and ash contents between treatment groups.

These values led to improve the meat quality and better effects to human health. Also, the increase in protein in rabbit meat can be attributed mainly to the presence of amino acids, vitamins, increase of protein digestibility as mentioned in Table (4) and trace elements of PPPs are nutritionally beneficial for improving intestinal absorption and digestion of all nutrient due the stimulus to the development proliferation and differentiation of intestinal cells and because they improve the environmental conditions for the intestinal microbial ecosystem.

\section{Blood constituents:-}

Results in Table (7) shows that there is a significant difference $(\mathrm{P}<0.05)$ in biochemical parameters was recorded as feeding inclusion levels of tested material. Significant differences were detected for plasma total protein, albumin and globulin. However, the increase in total protein, albumin and globulin was in a normal range as receiving 75\% PPPs may be associated with improvement of crude protein digestibility as shown in Table (4) and this result is in harmony with finding of Zeedan et al. (2015) and Brahmi, et al.(2012). Increase globulin concentration with increased PPPs inclusion which was observed in the present study may be an indication of increased immunity in the rabbits since the liver will be able to synthesize enough globulins for immunologic action. This explains the decrease in the mortality with increased PPPs analysis of variance shows that there is a significant effect due to dietary treatment an cholesterol, LDL, HDL and triglyceride was detected in this respect. All inclusion level of tested material 
decreased cholesterol, LDL, HDL and triglyceride compared to the control diet (Zeedan et al., (2015) and Wolfram, et al. (2002) reported that ingestion of fresh cladodes reduced cholesterol concentration.

Table (7): Effect of Prickly pear peels (PPPs) on some constituents in blood plasma of growing rabbits

\begin{tabular}{lccccc}
\hline Item & Control & $25 \%$ & $50 \%$ & $75 \%$ & L.S.D \\
\hline ALT & $27.28^{\mathrm{a}}$ & $25.64^{\mathrm{b}}$ & $25.10^{\mathrm{bc}}$ & $24.63^{\mathrm{c}}$ & 0.88663 \\
AST & $39.43^{\mathrm{a}}$ & $38.66^{\mathrm{b}}$ & $38.38^{\mathrm{b}}$ & $37.76^{\mathrm{c}}$ & 0.614333 \\
Total lipid & $5.28^{\mathrm{a}}$ & $4.68^{\mathrm{b}}$ & $4.36^{\mathrm{b}}$ & $3.67^{\mathrm{c}}$ & 0.33456 \\
LDL & $25.99^{\mathrm{a}}$ & $25.71^{\mathrm{ab}}$ & $25.05^{\mathrm{b}}$ & $25.92^{\mathrm{ab}}$ & 0.83689 \\
HDL & $55.60^{\mathrm{a}}$ & $52.84^{\mathrm{b}}$ & $46.95^{\mathrm{c}}$ & $45.10^{\mathrm{c}}$ & 1.99682 \\
Triglyceride & $1.57^{\mathrm{a}}$ & $1.52^{\mathrm{a}}$ & $1.46^{\mathrm{b}}$ & $1.42^{\mathrm{b}}$ & 0.054080 \\
Cholesterol & $81.59^{\mathrm{a}}$ & $78.55^{\mathrm{b}}$ & $72.01^{\mathrm{c}}$ & $71.02^{\mathrm{c}}$ & 1.770766 \\
Globulin & $2.23^{\mathrm{c}}$ & $2.90^{\mathrm{bc}}$ & $3.63^{\mathrm{ab}}$ & $3.85^{\mathrm{a}}$ & 0.7885312 \\
Albumin & $3.54^{\mathrm{a}}$ & $3.59^{\mathrm{a}}$ & $3.84^{\mathrm{a}}$ & $3.89^{\mathrm{a}}$ & $\mathrm{N} . \mathrm{S}$ \\
Total protein & $5.77^{\mathrm{c}}$ & $6.49^{\mathrm{b}}$ & $7.48^{\mathrm{a}}$ & $7.74^{\mathrm{a}}$ & 0.6225973 \\
Red blood & & & & NS* \\
cells $(\mathrm{N} \times$ & $4.08^{\mathrm{a}}$ & $4.25^{\mathrm{a}}$ & $4.50^{\mathrm{a}}$ & $4.66^{\mathrm{a}}$ & \\
$\left.10^{6} / \mathrm{mm}^{3}\right)$ & & & & NS* \\
White blood & & & & $5.93^{\mathrm{a}}$ & \\
cells $(\mathrm{N} \times$ & $5.56^{\mathrm{a}}$ & $5.60^{\mathrm{a}}$ & $5.63^{\mathrm{a}}$ & & \\
$\left.10^{3} / \mathrm{mm}^{3}\right)$ & & & &
\end{tabular}

Louacini, et al., (2012) showed that the pectin of opuntia tends to reduce cholesterol by binding to bile acids and the increases of their contcentrations enhance the catabolism of cholesterol. Feugang et al.,(2006) suggested that cactus pear reduces cholesterol levels in human blood and modify low density lipoprotein (LDL). The antioxidant properties of the most frequent cactus pear battalions (betanin and indicaxanthine ) have been revealed anti-hyperglycemia and regulator of blood cholesterol (Tesoriere et al., 2005, Stintzing and carle 2005), Zeedan et al. (2015) and Badr et al.,(2017). Overall, the effects of cactus are generally attributed to the high fiber content of the cladodes. The decrease of cholesterol levels may be directly related to the influence of PPPs an lipid metabolism.Liver function as AST and ALT activity were not affected by dietary treatments with supplementing PPPs.

Values of AST and ALT were within the normal range and indicated that the animals were generally in a good nutritional status and their livers were in a normal health condition. Plasma AST and ALT (Table 7) were determined as an indicator for enzymatic activity related to the rate of protein metabolism and liver function. It was showed that significant variations $(\mathrm{P}<0.05)$ were found for dietary treatments applied in liver functions. The protective effect of PPPs on some organs such as liver and brain may be due to its contents of some flavonoids which play a role as antioxidant against oxidative material which caused damage to such organs. These results are agreement with Stintzing and Carle (2005), Feugang et al. (2006), Abushammalah (2007) and Zeedan et al. (2015). Data in Table (7) illustrated that value of each of blood components including (red and white blood cells count) were increased in rabbits fed diet contained ppps than those of the control. The increase in WBCs in treated groups can be attributed mainly to the antibacterial functions, antimicrobial, anti-inflammatory activity and antioxidant of ppps (Ennouri et al., 2014; Zeedan et al. 2015 and Badr et al., 2017). Generally, the increase in blood constituents may be due to the role of ppp in improving all nutrient digestibility (Table 4). The improvements in the blood components of result of treatment with ppps may be due to the enhancement in the immune response (minerals and flavonoids have a role in enhancing immune system). Inclusion of the minerals composition are comprised of ( $\mathrm{Mg}, \mathrm{Ca}, \mathrm{K}, \mathrm{Na}, \mathrm{Cu}, \mathrm{Zn}, \mathrm{Mn}, \mathrm{P}$ and $\mathrm{Fe}$ ) vitamin $\mathrm{A}$, vitamin $\mathrm{E}$, vitamin $\mathrm{C}$, carotenoids, phenolic constituents and flavonoid (Stintzing and Carle, 2005; Feugang et al., 2006; Abushammalah, 2007; Cardador-Martinez et al., 2011; Cordova-Torres et al., 2015 and Badr et al., 2017).

\section{Economical efficiency:-}

The effects of dietary treatments on economical efficiency are presented in Table (8). The greatest total revenue and economical efficiency were calculated for rabbits fed diet containing $75 \%$ PPPs followed by $50 \%$ PPPs and $25 \%$ PPPs compared with control. The relative Economical efficiency values 
were 117.65, 141.58 and $159.84 \%$ for rabbits fed 25\%, 50\% and 75\% PPPs respectively. Badr Azza et al. (2017), and Zeedan et al (2015) Reported that the greatest total revenue and economical efficiency were calculated for rabbits fed diet containing 30\% cactus opuntia cladodes (COC) followed by $20 \%$ (COC) and 10\% (COC)compared with control AguilarYanez et al. (2011) reported that the economic analysis shows that feeding sheep with dehydrated and fresh spineless cactus, net gains increase to $16.23 \$$ and $17.84 \$$, respectively while, the control was only $12.98 \$$ (diets with dehydrated and fresh spineless cactus, respectively).

Table (8): Economical efficiency of Rabbits fed different experimental rations

\begin{tabular}{|c|c|c|c|c|c|c|c|c|}
\hline \multirow[t]{3}{*}{ Items } & \multicolumn{2}{|c|}{ control } & \multicolumn{2}{|c|}{$25 \%$} & \multicolumn{2}{|c|}{$50 \%$} & \multicolumn{2}{|c|}{$75 \%$} \\
\hline & weight & price & weight & price & weight & price & Weight & Price \\
\hline & $\mathrm{G}$ & L.E & $\mathrm{g}$ & L.E & $\mathrm{g}$ & L.E & $\mathrm{G}$ & L.E \\
\hline Initial live body weight (g) & 495.3 & 30 & 497.6 & 30 & 500.6 & 30 & 497.5 & 30 \\
\hline Final live body weight (g) & 1778.75 & & 1836.97 & & 1946.97 & & 1986.5 & \\
\hline Total gain $(\mathrm{g})$ & 1283.45 & 55.19 & 1339.37 & 57.59 & 1446.37 & 62.19 & 1489 & 64.02 \\
\hline Feed intake of feed $(\mathrm{g})$ & 4248 & & 4150 & & 4120 & & 4040 & \\
\hline Price $1 \mathrm{~kg}$ FI (L.E) & 5 & & 4.840 & & 4.680 & & 4.400 & \\
\hline Total feed cost/Rabbit (L.E) & & 21.24 & & 20.00 & & 19.30 & & 17.78 \\
\hline Cost of Kg gain/Rabbit (L.E) & & 16.55 & & 14.93 & & 13.34 & & 11.94 \\
\hline Total cost / Rabbit (L.E) & & 51.24 & & 50 & & 49.30 & & 47.78 \\
\hline Cost / kg BW (L.E) & & 28.81 & & 26.78 & & 25.32 & & 24.10 \\
\hline Total revenue & & 76.49 & & 78.99 & & 83.72 & & 85.42 \\
\hline Net revenue Rabbit (L.E) & & 25.25 & & 28.99 & & 34.42 & & 37.64 \\
\hline Economic efficiency & & 0.493 & & 0.580 & & 0.698 & & 0.788 \\
\hline Relative economic $\%$ & & 100 & & 117.65 & & 141.58 & & 159.84 \\
\hline
\end{tabular}

\section{CONCLUSION:}

Under the conditions of this, study it could be an advantageous to using PPPs to growing rabbits without any adverse effect on health. The prickly pear peels (PPPs) will have appositive influence on the health primarily aiming to improve immune status of rabbits, improve their growth performances, digestibility and nutritive value, cecum traits, carcass characteristics, some blood constituents and economical efficiency. It can be concluded that (PPPs) feed as available and very low cost feed can be used as a partial feed to maintain rabbit's growth under unavoidable economical conditions and higher feed prices in Egypt. However, there is need of chemical and nutritional evaluations and more work is required for the application of PPPs in in-vivo trails for feeding ruminants.

\section{REFERENCES}

Abu Shammalah, K. N. (2007). Evaluation of Cactus (Opuntia Sp.) as Forage Source for Growing Rabbits in the Gaza Strip. M.Sc. Thesis, the Islamic Univ. -Gaza, Faculty of Sci. Master of Biological Sci..

Aguilar-Yáñez, M. I., O. Hernández-Mendo , I. Guerrero-Legarreta, J.E. Ramírez-Bribiesca, G. Aranda-Osorio and M.M. Crosby-Galvan (2011). Productive response of lambs fed with fresh or dehydrated spineless cactus (Opuntia ficus-indica L.). J. PACD 13: 23-35.

Ahmed, B. M. (1976). The use of non-protein nitrogenous compounds in rabbit rations. M. Sc. Thesis. Tanta Univ.

Amare D, S. Melaku and G. Berhane (2009). Supplementation of iso nitrogenous oil seed cakes in cactus (Opuntia ficus-indica)-tef straw (Eragrostis tef) based feeding of Tigray Highland sheep, Anim. Feed Sci. Technol., 148 (2-4), 214-226 
Anonymous (2008): Annual report of statistical analysis section. Economic research institute. Agricultural Research Center. Ministry of Agriculture.

AOAC (1995). Official Methods of Analysis (Sixteenth Edition) Assosiation of Officia Analytical Chemists Washington, D.C.

AOAC (2002). Official Methods of Analysis of the Association of Official Analytical Chemists, 17 th ed. Van Soest, P.J.; J.B., Robertson and B.A., Lewis; (1991): Methods of dietary fiber, neutral detergent fiber and non-starch polysaccharide in relation to animal nutrition. J. Dairy Sci.74, 35833597.Gaithersburg, Maryland, USA.

Atti, N., M. Mahouachi and H. Rouissi (2006). The effect of spineless cactus (Opuntia ficus-indica f. intermis) supplementation on growth, carcass, meat quality and fatty acid composition of male goat kids. Meat Sci. 73: 229-235.

Atti, N., M. Mahouachi, F. Zouaghi and H. Rouissi (2009). Incorporation of cactus (Opuntia ficus-indica f. inermis) in young goats diets: 1. Effects on intake, digestion, growth and carcass composition. Livestock Res. for Rural Devel. 21 (12): 217-230.

Badr Azza. M.M., A.A. Bakr and M.M. El-Shinnawy (2017). Prediction the nutritive value of prickly pear peels as a natural unconventional feed resource for feeding ruminants from chemical composition and in vitro digestibility using DAISY II incubator technology. Egyptian J. Nutr. and Feeds, 20:( 2).

Badr, S. E. A.; A.A. bakr; Gihan M. El-moghazy and O. A. Wahdan (2017). Anticancer activity and hypolipidemic effect of methanolic and ethanolic prickly pear cactus peel extracts. Egypt. Nut. Society Issue. The first International conference of nutrition, Hurghada, April.

Bassuny, S.M.; A.A. Abdel-Aziz; M.F. EL-Sayis and M.A. Abdula (2003). Fibrous crops by-product as feed.2- Effect of chemical and chemi biological treatments on feed intake, nutritive values some ruminal and blood constituents. Egypt J. Nut. and Feed, 6 (Special Issue ):901-912.

Batista, A. M., A.F. Mustafa, T. McAllister, Y. Wang, H. Soita and J.J. McKinnon (2003). Effects of variety on chemical composition, in situ nutrient disappearance and in vitro gas

Ben Salem, H. and T. Smith (2008). Feeding strategies to increase small ruminant production in dry environments. Small Rum. Res. 77: 174-194.

Ben Salem, H., A. Nefzaoui, H. Abdouli and E.R. Ørskov (1996). Effect of increasing level of spineless cactus (Opuntia ficus-indica var. Inermis) on intake and digestion by sheep given straw-based diets. Anim. Sci. 62:293-299.

Ben Salem, H., H. Abdouli, A. Nefzaoui, L. Ben Salem El-Mastouri (2005). Nutritive value, behaviour, and growth of Barbarine lambs fed on oldman saltbush (Atriplex nummularia L.) Tesoriere, L., Butera, D., Pintaudi, M., Allegra, M. and Livera, M. A. (2004). Supplementation with cactus pear (Opuntia ficus-indica) fruit decreases oxidative stress in healthy humans: a comparative study with Vit. C. Am. J. Clinique. Nut. 80: 391-395.

Bisop S.V., M.A. Ferreira and A.S.C. Veras (2007). Palma forrageira em substituição ao feno de capimelefante: efeito sobre consumo, digestibilidade e características de fermentação ruminal em ovinos. R. Bras. Zootec. 36:1902-1909.

Brahmi, D., Y. Ayed, M. Hfaiedh, C. Bouaziz, H. Ben Mansour, L. Zourgui and H. Bacha (2012). Protective effect of cactus cladode extract against cisplatin induced oxidative stress, genotoxicity and apoptosis in balb/c mice: combination with phytochemical composition. BMC Complementary and Alternative Medicine, 12:111

Burt, S. (2004). Essential oils: their antibacterial properties and potential applications in foods-a review. Int. J. Food Microbiol. 94: 223-253

Cardador-Martínez, A., C. Jiménez-Martínez, and G. Sandoval (2011). Revalorization of cactus pear (Opuntia spp.) wastes as a source of antioxidants. Ciênc. Technol. Aliment, Campinas, 31(3): 782788.

Cheeke, P. R.; N.M. Patton and G.S. Tempelton (1982). Rabbit Production. 5th Edition, Interstate Printers and Publishers Danville II., USA. 
Cordova-Torres, A.V., J.C. Mendoza-Mendoza, G. Bernal-Santos, T. García-Gasca, J.R. Kawas, R.G. Costa, C. Mondragon Jacoboa and H.M. Andrade-Montemayor (2015). Nutritional Composition, in vitro Degradability and Gas Production of Opuntia ficus indica and Four Other Wild Cacti Species. Life Sci. J. 12(2s):42-54

Costa, R. G., I.H. Trevino, G.R. de Medeiros, A.N. Medeiros, T.F. Pinto, R.L. de Oliveira (2012). Effects of replacing corn with cactus pear (Opuntia ficus indica Mill) on the performance of Santa Inês lambs. Small Rum. Res. 102: 13-17.

Cowan MM. (1999). Plant products as antimicrobial agents. Clin. Microbiol. Rev. 12:564-582. Einkamerer, O. B. (2008). Animal performance and utilization of Opuntia-based diets by sheep. M.Sc. Agric. Thesis. Univ. of the Free State, Bloemfontein, S. Afr.

DeKock, G.C. (1980). Drought resistant fodder shrub crops in South Africa. In: Le Houerou, H.N. (ed.) Browse in Africa: The current state of knowledge. ILCA, Ethiopia. pp. 109-114.

Deraz, A. and H. Ismail (2001). Cotton stalks treated with white -rot Fungi for feeding sheep. Egypt J. Nutr. Feeds, 4 (Special Issue):433-434.

detergent fiber and non-starch polysaccharide in relation to animal nutrition. J. Dairy Sci.74, 3583-3597.

Duncan, D.B. (1955). Multiple range and multiple F-test. Biometrics, 11:1-42.

Einkamerer, O. B. (2008). Animal performance and utilization of Opuntia-based diets by sheep. M.Sc. Agric. Thesis. Univ. of the Free State, Bloemfontein, S. Afr.

Einkamerer, O.B., H.O. De Waal, W.J. Combrinck and M.D. Fair (2009). Feed utilization and growth of Dorper wethers on Opuntia-based diets. S. Afr. J. of Anim. Sci. 39: 53-57.

El- Shinnawy, A. M. and M. M. T. Eassawy (2016). Improving potato vine utilization by sheep using biocem treatment. J. Animal and poultry prod., Mansoura Univ.m vol. 7(9):323-330.

El- Shinnawy, M.M.; M.F. Emara; H.F.A. Motawe; Fatma, M. Salman and A. M.El. Shinnawy (2011). Effect of two kinds of bacteria inoculants on preservation and nutritive values of urine broad bean silages compared with clover hay. The $4^{\text {th }}$ Scientific conference of animal Welth Research Conf. in the Middle East and North Africa.

EL-Ashry, M.A.; A.M. Kholif; H.M. EL-Sayed; M. Fadel and S.M. Kholif (2001). Biological treatments of banana wastes for lactating goats feeding. Proc.8th Conf. Animal Nutri. 23-26 October, Sharm ELSheikh, Egypt.

El-Said, N.M.; A.I. Nagib; Z. A. Rahman and S. F. Deraz (2011). Prickly pear \{Opuntia ficus. Indica (L)mill\} peels: Chemical composition, nutritional value and protective effects on liver and kidney functions and cholesterol in rats. Functional plant Science and Biotechnology, Global science books

El-Shinnawy (2011). Effect of two kinds of bacteria inoculants on preservation and nutritive values of urine broad bean silages compared with clover hay. The $4^{\text {th }}$ Scientific conference of animal Welth Research Conf. in the Middle East and North Africa.

Ennouri, M.; I. Ammar; B. Khemakhem; H. Attia (2014). Chemical Composition and Antibacterial Activity of Opuntia Ficus-Indica F. Inermis (Cactus Pear) Flowers. J. Med. Food, 17:908-914.

Fekete, S and T. Gippert (1986). Digestibility and nutritive value of nineteen feedstuffs. J. Appl. Rabbit Res., 9: 103- 108 .

Feldman, B. F.; J.G. Zinkl and N.C. Jain (2000). Schalm's Veterinary Hematology. Lippincott Williams and Wilkins, Philadelphia, USA.

Felker, P. (1995). Forage and fodder production and utilization. In: G. Barbera, P., Inglese and E. Pimienta-Barrios (eds.). Agro-ecology, cultivation and uses of cactus pear. FAO Plant Production and Protection Paper 132. Rome. pp.144-154.

Feugang, J.M., P. Konarski, D. Zou, F.C. Stintzing, C. Zou (2006). Nutritional and medicinal use of cactus pear (opuntia spp.) cladodes and fruits. Frontiers in Bioscience. 11: 2574-2589.

Flachowsky, G and A. Yami (1985). Composition, digestibility and feed intake of Opuntia by Ogade sheep. Archiv-für-Tierernahrung. 35, 599-606. (Abstract). 
Gebremariam, T. S.; S. Melaku and A. Yami (2006). Effect of different levels of cactus (Opuntia ficusindica) inclusion on feed intake, digestibility and body weight gain in teff (Eragrostis teff) straw-based feeding of sheep. Ani. Feed Sci. and Tech. 131: 42-51.

Gregory, R.A. and P. Felker (1992). Crude protein and phosphorus contents of eight contrasting Opuntia forage clones. Journal of Arid Environment. 22, 323-331.

Habibi Y, M. Mahrouz and M.R. Vignon (2005). Isolation and structural characterization of protopectin from the skin of Opuntia ficus-indica prickly pear fruits. Carbohydrate Polymers 60: 205-213.

Hanselka, C.W. and J.C. Paschal (1990). Prickly pear cactus: an important rangeland resource. Progress report. Texas agricultural experiment station. Beef cattle research in Texas. (Abstract). Hanselka, C.W. and J.C. Paschal. 1991. Prickly pear cactus: an important rangeland resource. In: Progress Report, pp. 141-143. Texas Agr. Exp. Sta., U.S.A.

Hoffman, M. T., C.D. James, G.I.H. Kerley and W.G. Whitford (1993). Rabbit herb ivory and its effect on cladode, flower and fruit production of opuntia violacea var macrocentra (cactaceae) in the northern Chihuahuan desert, New Mexico. The southwestern Naturalist, 38 (4): 309-315

Kamel B.S., and y. Kakuda (2002).Fatty acids in fruits and fruits products. In: chow CK,(ED.) fatty acids in food and their health Implication (2nd Edn.), Mar-cel Dekker, New Yourk.Pp239-270.

Kaur, M., A. Kaur and R. Sharma (2012). Pharmacological actions of Opuntia ficus indica: A Review. J. Appl. Pharmaceutical Sci. 2: 15-18.

Lakshminarayana (1980). Sapodilla and prickly pear. In: Nagy S. Shaw PE (Eds.) Tropical and

Leslie, H. and C.H. Frank (1989). Practical Immunology. Third ed. pp. 23.

López, G.J.J., R.J.M. Fuentesand and R.A., Rodríguez (2001). Production and use of Opuntia as forage in northern Mexico. In: Mondragon, C. and Gonzalez, S. (eds.). Cactus (Opuntia spp.) as forage. FAO Plant Production and Protection Paper, 169. Rome. pp. 29-36.

Louacini, B., D. Abdelkader, M. Halbouche and K. Ghazi (2012). Effect of incorporation of the spineless opuntia ficus indica in diets on biochemical parameters and its impact on the average weight of ewes during the maintenance. Global Vet. 8 (4): 352-359.

Mahouachi, M., N. Atti and H. Hajji (2012). Use of spineless cactus (opuntia ficus indica f. inermis) for dairy goats and growing kids: impacts on milk production, kid's growth, and meat quality. The Scientific World J. Volume 2012, Article ID 321567, 4 pages. doi:10.1100/2012/321567

Mendez-Liorente, F., R.G. Ramírez-Lozano, J.I. Aguilera-Soto and C.F. Arechiga-Flores (2008). Performance and nutrient digestion of lambs fed incremental levels of wild cactus (Opuntia leucotrichia). Conference on International Research on Food Security, Natural Resource Management and Rural

Menezes, C.M.D., L.M.J. Schwalbach, W.J. Combrinck, M.D. Fair and H.O. Dewaal (2010). Effects of sun-dried Opuntia ficus-indica on feed and water intake and excretion of urine and faeces by Dorper sheep. S. Afr. J. Anim. Sci. 40 (5):491-494.

Misra, A. K., A.S. Mishra, M.K. Tripathi, O.H. Chaturvedi, S. Vaithiyanathan, R. Prasad and R.C. Jakhmola (2006). Intake, digestion and microbial protein synthesis in sheep on hay supplemented with prickly pear cactus [Opuntia ficus-indica (L.) Mill.] with or without groundnut meal. Small Rum. Res. 63:125-134.

North, M. O. (1981). Commercial chicken production. Annual. 2nd Edition. Av. Publishing company I. N. C., West-post Connecticut. U.S.A

NRC (1977). National Research Council: Nutrient Requirements of Rabbits. 2nd Revised Edition, National Academy of Sciences, Washington, DC. USA.

Ruiz-Feria, C. A., S. D. Lukefahr, M. A Pro., C. P. Becerril, and P. Felker (1996). Cactus (Opuntia stricta) and mesquite (Prosopis glandulosa var. glandulosa) as forage resources for growing rabbits in semi-arid, subtropical south Texas. In: Proc 6th World Rabbit Congress, Toulouse, France, 3:257-261.

Ruiz-Feria, C. A., S.D. Lukefahr and P. Felker (1998). Evaluation of Leucaena leucocephala and cactus as forages for growing rabbits. Livestock Res. for Rural Development. http://www.cipav.org.co/lrrd/lrrd10/2/luke102.htm 
SAS. (1998). JMP User's Guide, Version 3.1. SAS Institute Inc., N.C.

Steven, W. D.; W.D. Hohenboken; P.R. Cheeke; N.M. Patton and W.H. Kennick (1981). Carcass and meat characteristics of Flernish Giant and New Zealand White purebred and terminal cross rabbits. J. App. Rabbit Res., 4: 66.

Stintzing, F.C. and R. Carle (2005). Cactus stems (Opuntia spp.): A review on their chemistry technology, and uses. Molecular Nut. and Food Res. 49:175-194.

Stintzing; F.C; A. Schieber and R. Carle (2000). Cactus pear, a promising component of functional food Obst- Gemils and Kartoffeluerarheitung 85:40-47.

subtropical fruits. Composition properties and uses. AVI. West port. CT:415-44.

Taddesse, D., S. Melakub and Y. Mekashac (2014). Effect of Supplementation of Cactus and Selected Browses Mix on Feed Utilization of Somali Goats. American Scientific Res. J. for Eng., Tech. and Sci. 9 (1): 20-34.

Tegegne, F., C. Kijora and K.J. Peters (2005). Study on the effects of incorporating various levels of cactus pear (Opuntia ficus-indica) on the performance of sheep. Conf. on Inte. Agric. Res. for Development. Stuttgart-Hohenheim, October 11-13.

Terrazas, J. J.; R.I. Basurrn; J. C. Montadez- Saeuz; M.I. Agular; R. Nega and J. C. Contreras- Esquivel (2002). Pricky pear (Opuntia ficus- Indica) peels as a new desert fiber. Preparation and partial characterization. In: Annual Meeting and Food. Expo Anaheim, CA, California: 114

Tesoriere L., D. Butera, M. Allegra, M. Fazzari and M.A. Livrea (2005). Distribution of betalain pigments in red blood cells after consumption of cactus pear fruits and increased resistance of the cells to ex vivo induced oxidative hemolysis in humans. J. of Agric. and Food Chem. 53: 1266-1270. and supplemented or not with barley grains or spineless cactus (Opuntia ficus-indica f. inermis) pads. Small Rum. Res. 59: 229-237.

Van Soest, P.J.; J.B. Robertson and B.A. Lewis. (1991). Methods of dietary fiber, neutral

Vieira E. L., A. M. V. Batista, A. Guim, F. F. Carvalho, A. C. Nascimento, R. F. S. Araújo, A. F. Mustafa (2008). Effects of hay inclusion on intake, in vivo nutrient utilization and ruminal fermentation of goats fed spineless.

Wanderley, W. L., M.A. Ferreira, D.K.B. Andrade, A.S.C. Véras, I. Farias, L.E. Lima and A.M.A. Dias (2002). Replacement of forage cactus (Opuntia fícus indica Mill) for sorghum silage (Sorghum bicolor (L.)Moench) in the dairy cows feeding. Rev.Bras.Zootec. 31: 273-281.

Wolfram, R. M., H. Kritz, P. Schmid, Y.E. fthimiou, Y. Stamatopoulos and H. Sinzinger (2002). Effect of prickly pear (Opuntia robusta) onglucose- and lipid-metabolism in non diabetics with hyperlipidemia, Wr klin Wschr, 114: 840-846.

Zeedan, Kh.; I. I. Zeedan, Battaa, A. M. El-Neney, A. I. Abd EL. Lateif, Nasra B. Awadien and T. A. Ebeid (2015). Effect of using residues prickly pear as a source of dietary feed staffs on productive performance, biological treats and immune response of rabbits. Egyptian Poultry Science Journal ISSN: 1110-5623 (Print) - 2090-0570 (On line).

Zeeman, D. Z. (2005). Evaluation of sun-dried Opuntia ficus-indica var. Algerian cladodes in sheep diets. M.Sc. Agric. Thesis. Univ. of the Free State, Bloemfontein. 
تأثير استبدال دريس البرسيم بقشور التين الثوكي علي الأداء الإنتاجي للإرانب

\author{
عادل احمد بكر \\ المركز الاقليمى للأغنية والاعلاف - مركز البحوث الزراعية ـ الجيزة
}

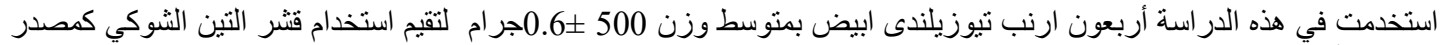

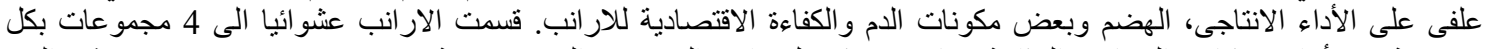

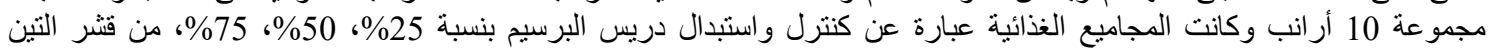

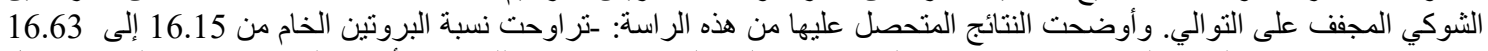

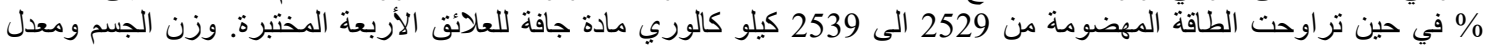

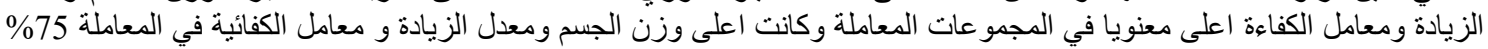

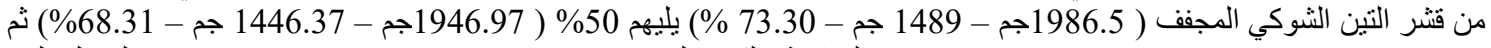

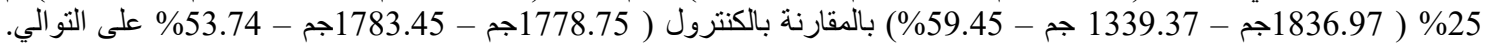
حدث تحسن معنويا في قيم معاملات هضم ADL ، ADF، NDF، NFE، CF، CP،DM للعلائق المغذاة على قشر التين الثوكي

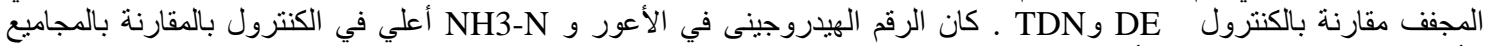

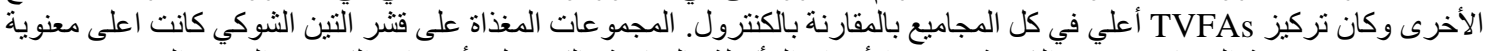

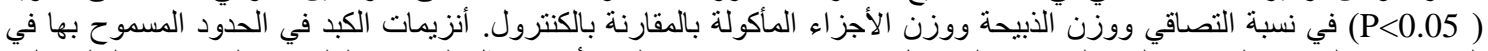

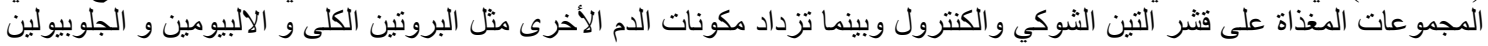

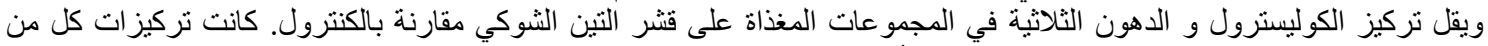

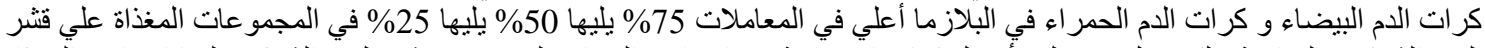

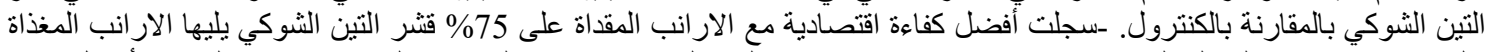

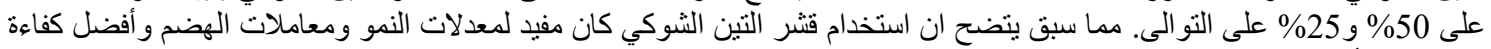
اقتصادية للأرانب النيوذلاندي.
\end{abstract}

